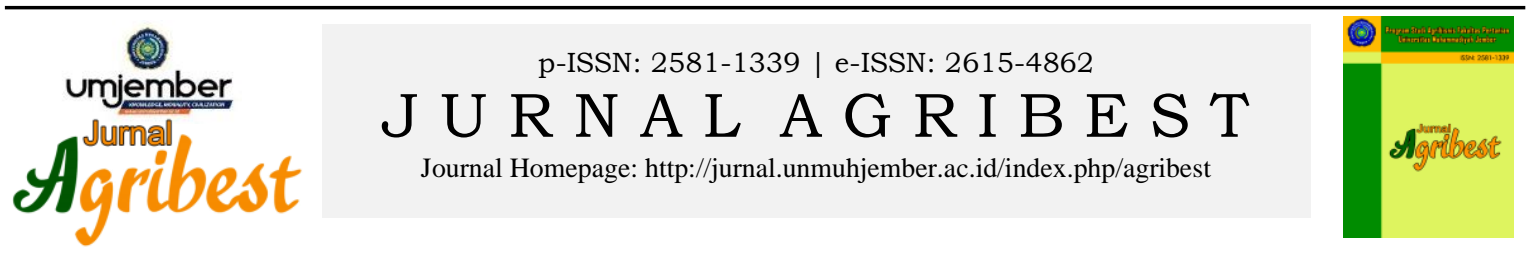

\title{
Model Kebijakan Pengendalian Harga Bahan Pokok Pada Masa Pandemi Covid-19 Di Kaupaten Situbondo
}

\author{
Model Kebijakan Pengendalian Harga Bahan Pokok Pada Masa Pandemi \\ Covid-19 Di Kaupaten Situbondo \\ Moh. Rasidi ${ }^{1}$, Ramli $^{2}$ \\ ${ }^{1}$ Universitas Nurul Jadid \\ ${ }^{2}$ Universitas Ibrahimy \\ email: muhammad.rosyidi09@gmail.com,ramliarul80@gmail.com
}

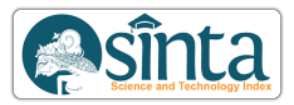

Received: 2021-01-15 Accepted: 2021-02-06 Published: 2021-03-25

This work is licensed under a Creative Commons Attribution 4.0 International License. Copyright (c) 2021 Jurnal Agribest

(CC) (i) Br.

Corresponding Author: Moh Rasidi, Universitas Nurul Jadid, muhammad.rosyidi09@gmail.com

\begin{abstract}
ABSTRAK
Pandemi covid-19 tidak hanya berdampak pada krisis kesehatan tapi sektor ekonomi juga mengalami krisis. Di sektor ekonomi, dampak Covid 19 terjadi pada kenaikan harga bahan pokok di pasaran. Oleh karena itu perlu intervensi dari Pemerintah Daerah Kabupaten Situbondo dengan merancang model kebijakan pengendalian harga bahan pokok dimasa pandemi covid-19 ini, sehingga harga bahan pokok tetap terkendali dan kebutuhan masyarakat atas bahan pokok tetap bisa terpenuhi. Tujuan penelitian ini adalah untuk merancang model kebijakan pengendalian harga bahan pokok pada masa pandemi covid-19 di Kabupaten Situbondo. Metode yang digunakan dalam penelitian ini adalah teknik Interpretative Structural Modelling (ISM). Hasil penelitian menunjukkan bahwa model kebijakan pengendalian harga bahan pokok pada masa pandemi covid-19 di Kabupaten Situbondo terdiri dari empat elemen kunci yang terdiri dari (1) tujuan kunci, yaitu mengendalikan harga bahan pokok dan mengalokasikan anggaran untuk pengendalian harga bahan pokok, dalam hal ini program harus fokus pada pengendalian harga dan alokasi anggaran untuk pengendalian harga, (2) masyarakat kunci, yaitu Pemerintah Daerah, dalam hal ini Pemerintah Daerah menjadi pendorong kunci terhadap keberhasilan pengendalian harga bahan pokok, (3) aktivitas kunci, yaitu meningkatkan kinerja Tim Pengendali Inflasi Daerah (TPID), dalam hal ini kualitas kinerja TPID akan menentukan keberhasilan program pengendalian harga bahan pokok dan (4) lembaga kunci, yaitu Pemerintah Daerah dan DPRD, hal ini diperlukan sinergitas yang kuat antara pemerintah Daerah (eksekutif) dengan DPRD (legislatif) dalam melahirkan kebijakan berupa Peraturan Daerah tentang pengendalian harga bahan pokok. Keempat elemen kunci tersebut akan menjadi motor terwujudnya stabilitas harga bahan pokok pada masa pandemi covid-19 di Kabupaten Situbondo
\end{abstract}

Kata kunci : Model kebijakan; bahan pokok; covid-19

\section{ABSTRACT}

The covid-19 pandemic not only has an impact on the health crisis but the economic sector is also experiencing a crisis. In the economic sector, the impact of Covid 19 occurred in the increase in prices of basic commodities on the market. Therefore it is necessary to intervene from the regional government of Situbondo Regency by designing a policy model for controlling the price of basic commodities during the Covid-19 pandemic, so that prices of basic commodities remain under control and people's needs for basic commodities can still be met. The purpose of this study was to design a policy model for controlling the price of basic commodities during the Covid-19 pandemic in Situbondo Regency. The method used in this research is the technique of Interpretative Structural Modeling. The results show that the policy model for controlling the price of basic commodities during the Covid-19 pandemic in Situbondo Regency consists of four key elements consisting of (1) key objectives, namely controlling the prices of basic commodities and allocating a budget for controlling the prices of basic commodities, in this case the program should focus on price control and budget allocation for price control (2) key community, namely the Regional Government, in this case the local government becomes the key driver for the success of controlling the prices of basic commodities (3) key activities, namely improving the performance of the Regional Inflation Control Team, The performance 
quality of the Regional Inflation Control Team will determine the success of the program to control the price of basic commodities and (4) key institutions, namely the Regional Government and the regional parliaments, This requires a strong synergy between the Regional executive and the legislative in creating policies in the form of Regional Regulations on controlling prices of basic commodities. These four key elements will become the motor for the realization of price stability of basic commodities during the Covid-19 pandemic in Situbondo Regency.

Key words: Policy model; basic commodities; covid-19

\section{PENDAHULUAN}

Pemerintah sebagai salah satu pelaku ekonomi (rumah tangga pemerintah), memiliki fungsi penting dalam perekonomian yaitu berfungsi sebagai stabilisasi, alokasi, dan distribusi. Dari sudut pandang ilmu negara, fungsi stabilitasi merupakan ciri negara yang utama. Di antara fungsi stabilitasi ini adalah untuk mencegah kegagalan pasar (market failure), yang dapat berefek tergerusnya pemenuhan kebutuhan rakyat (Sumarni, 2013).

Pemerintah akan berhasil melaksanakan fungsi stabilisasi, jika mampu mengendalikan mekanisme pasar. Mekanisme pasar pada intinya adalah mekanisme harga, pada mekanisme harga ditentukan oleh permintaan (supply) dan penawaran (demand). Suatu permintaan dan penawaran adalah kekuatan yang saling terkait sehingga membentuk suatu komunitas pasar. Bila suatu permintaan terjadi secara alami dan normal, maka suatu kegiatan pasar akan berjalan stabil dan kondusif, tetapi sebaliknya bila pasar berjalan tidak normal dan penuh rekayasa, maka akan rusak. Di sinilah peran pemerintah dalam mekanisme pasar perlu mendapatkan perhatian utama tanpa mengorbankan potensi manusia dalam mengembangkan aktifitas ekonomi. Salah satu peran pemerintah dalam mengatur mekanisme pasar adalah menetapkan lembaga pengawas pasar (market supervision), keberadaan institusi ini sebagai regulator atau pengawas dalam proses mekanisme pasar terutama mengontrol harga dan para pelaku pasar. (Rahmi, 2015)

Pengendalian mekanisme pasar sebagai upaya menjaga stabilitas harga bahan pokok tidak hanya menjadi tanggungjawab pemerintah pusat tapi pemerintah Daerah juga memiliki tanggung jawab untuk menjaga stabilitas harga bahan pokok diwilayahnya. Jika Pemerintah Daerah menyerahkan sepenuhnya harga bahan pokok pada mekanisme pasar, bisa dipastikan harga bahan pokok akan tidak stabil atau fluktuatif sehingga akan mengganggu daya beli masyarakat, apalagi di masa pandemi covid-19 seperti sekarang ini, kenaikan harga semakin kentara, daya rusaknya lebih berat dari hari-hari biasa (Hasan, 2016)

Pandemi covid-19 tidak hanya berdampak pada krisis kesehatan tapi sektor ekonomi juga mengalami krisis. Di sektor ekonomi, dampak Covid 19 terjadi pada kenaikan harga bahan pook di pasaran. Memasuki akhir tahun 2020, kenaikan harga semakin meningkat tajam, khususnya pada harga kebutuhan bahan pokok, seperti gula, minyak goreng, dan telur. Kenaikan harga juga terjadi pada bahan pokok lainnya seperti buah dan sayur-sayuran yang merupakan kebutuhan penting sebagai konsumsi sehari-hari agar tetap sehat di masa Pandemi Covid 19 (Anonimous, 2020)

Fluktuasi harga bahan pokok sebagai dampak dari pandemi covid-19 juga di rasakan masyarakat Kabupaten Situbondo. Berdasarkan hasil pemantauan perkembangan harga kebutuhan bahan pokok oleh dinas Perdagangan dan Perindustrian Kabupaten Situbondo pada bulan januari sampai Desember Tahun 2020, fluktuasi harga terjadi pada sayur-sayuran, Cabe dan bawang, sementara harga beras, gula dan minyak goreng relatif stabil, hal ini dikarenakan adanya bansos sembako dari pemerintah pusat dan pemerintah Daerah (Disperindag, 2020)

Melonjaknya sebagian harga bahan pokok di Kabupaten Situbondo di masa Pandemi Covid 19 berdampak pada menurunnya daya beli masyarakat, karena Pandemi Covid 19 juga berdampak pada naiknya angka pengangguran dan menurunnya penghasilan sebagian besar masyarakat di Kabupaten Situbondo. Oleh karena itu perlu intervensi dari Pemerintah Daerah Kabupaten Situbondo dengan merancang model kebijakan pengendalian harga bahan pokok dimasa pandemi covid-19 ini, sehingga harga bahan pokok tetap terkendali dan kebutuhan masyarakat atas bahan pokok tetap bisa terpenuhi. Tujuan penelitian ini adalah untuk merancang model kebijakan pengendalian harga bahan pokok pada masa pandemi covid-19 di Kaupaten Situbondo. 
Jurnal Agribest Volume X Nomor X (2020) Hal: 34-44

DOI: https://doi.org/ 10.32528/agribest.v5i1.4140

\section{METODE PENELITIAN}

Penelitian ini dilaksanakan di Kabupaten Situbondo pada Bulan Desember 2020 sampai Januari 2021. Metode pengumpulan data dalam penelitian ini adalah dengan Wawancara terstruktur dan semi terstruktur. Wawancara terstruktur adalah wawancara yang dilakukan dengan terlebih dahulu membuat pertanyaan dan kemudian menyusun pertanyaan dalam bentuk daftar-daftar pertanyaan yang akan diajukan kepada informan, sedangkan Wawancara semi terstruktur dilakukan berdasarkan pada beberapa pertanyaan dan topik yang sudah ditentukan sebelumnya. Karakteristik responden yang terlibat dalam wawancara, terdiri dari beberapa pakar yang memiliki pengetahuan, pemahaman dan wawasan yang luas mengenai Kebijakan pengendalian harga bahan pokok. Metode yang digunakan untuk menggunakan model kebijakan pengendalian harga bahan pokok pada masa pandemi covid-19 di Kabupaten Situbondo adalah teknik Interpretative Structural Modelling (ISM). Menurut Fadhil, et.al (2018), Teknik ISM ini dapat digunakan untuk melakukan analisis program sesuai visi dan misi. Secara garis besar teknik ISM dibagi menjadi dua bagian, yaitu klasifikasi elemen dan penyusunan hirarki. Teknik ISM ini intinya adalah klasifikasi elemen dan penyusunan hirarki. Terdapat 9 elemen indikator dalam analisis ISM yaitu (1) sektor masyarakat yang terpengaruh, (2) kebutuhan dari program, (3) kendala utama program, (4) perubahan yang dimungkinkan dari program, (5) tujuan dari program, (6) tolok ukur untuk menilai setiap tujuan, (7) aktivitas yang dibutuhkan guna perencanaan tindakan, (8) ukuran aktivitas guna mengevaluasi hasil yang dicapai oleh setiap aktivitas dan (9) lembaga yang terlibat dalam pelaksanaan program. Langkah-langkah analisis dengan menggunakan ISM adalah sebagai berikut:

(1) Penyusunan sub elemen pada masing-masing elemen dan melakukan analisis hubungan kontesktual bahwa satu subelemen (subelemen i) mendukung keberadaan subelemen yang lain (subelemen $\mathrm{j}$ ). Hubungan kontektual antara subelemen ini diperoleh dari pendapat pakar yang memberikan pendapatnya melalui wawancara semi terstruktur.

(2) Informasi dari sistem yang dikaji kemudian distrukturisasi dalam bentuk Structural Selfinterction Matrix (SSIM) yang menggambarkan hubungan kontekstual antar subelemen dan elemen elemen sistem. Penyusunan SSIM menggunakan simbol V, A, X, dan O. Pengertian dari simbol-simbol tersebut adalah:

$\mathrm{V}$ : kendala (1) mempengaruhi kendala (2), tapi tidak sebaliknya

$\mathrm{V}:$ eij $=1$ dan eij $=0$

A : kendala (2) mempengaruhi kendala (1), tapi tidak sebaliknya

A: $\mathrm{eij}=0$ dan eij $=1$

$X$ : kendala (1) dan kendala (2) saling berhubungan

$\mathrm{X}:$ eij $=1$ dan eij $=1$

$\mathrm{O}$ : kendala (1) kendala (2), tidak saling mempengruhi

O: eij $=0$ dan eij $=0$

Simbol 1 adalah terdapat atau ada hubungan kontekstual, sedangkan simbol 0 tidak terdapat atau tidak ada hubungan kontekstual antara elemen i dan j dan sebaliknya. Setelah SSIM terbentuk, kemudian dibuat tabel Reachability Matrix (RM) dengan mengganti simbol V, A, $\mathrm{X}$, dan $\mathrm{O}$ menjadi bilangan 1 atau 0 .

(3) RM yang telah memenuhi aturan transitivitas kemudian diolah untuk menetapkan level partition. Hasilnya dapat digambarkan dalam bentuk skema setiap sub elemen menurut jenjang vertikal dan horizontal. Berdasarkan RM, sub elemen dalam satu elemen dapat disusun menurut nilai Driver-Power (DP) dan nilai Dependence (D) untuk menentukan klasifikasi sub elemen.

(4) Secara garis besar klasifikasi sub elemen dikelompokan dalam empat sektor yaitu :

- Sektor 1; weak driver - weak dependence variables (Autonomus). Subelemen yang termasuk dalam sektor ini pada umumnya tidak berkaitan dengan sistem, dan mungkin mempunyai hubungan sedikit, meskipun hubungan tersebut bisa saja kuat. Subelemen yang masuk pada sektor $1 \mathrm{jika}$; nilai $\mathrm{DP} \leq 0,5 \mathrm{X}$ dan nilai $\mathrm{D} \leq 0,5 \mathrm{X}$. $\mathrm{X}$ adalah jumlah subelemen.

- Sektor 2; weak driver - strongly dependence variables (Dependence). Umumnya subelemen yang masuk pada sektor ini adalah subelemen bebas. Subelemen yang masuk pada sektor 2; jika nilai $\mathrm{DP} \leq 0,5 \mathrm{X}$ dan nilai $\mathrm{D}>0,5 \mathrm{X}$. X adalah jumlah subelemen. 
- Sektor 3; strong driver - strongly dependent variables (Lingkage). Subelemen yang termasuk dalam sektor ini harus dikaji secara hati-hati, sebab hubungan antara subelemen tidak stabil. Setiap tindakan pada subelemen akan memberikan dampak terhadap subelemen lainnya dan pengaruh umpan baliknya dapat memperbesar dampak. Subelemen yang masuk sektor 3; jika nilai DP $>0,5 \mathrm{X}$ dan nilai $\mathrm{D}>0,5 \mathrm{X}$. X adalah jumlah subelemen.

Sektor 4; strong driver - weak dependence variables (Independent). Subelemen yang masuk dalam sektor ini merupakan bagian sisa dari sistem dan disebut peubah bebas. Subelemen yang masuk sektor 4 jika: nilai $\mathrm{DP}>0,5 \mathrm{X}$ dan nilai $\mathrm{D} \leq 0,5 \mathrm{X}$. $\mathrm{X}$ adalah jumlah subelemen pada penelitian ini.

\section{HASIL DAN PEMBAHASAN}

Interpretative structural modelling (ISM) digunakan untuk melihat hubungan antar komponen di dalam sistem. Untuk merancang model yang dapat mendukung kebijakan pengendalian harga bahan pokok, dipilih elemen-elemen yang berperan secara dominan dalam merancang model kebijakan pengendalian harga bahan pokok (Sianipar, 2012). Dari 9 elemen yang dikembangkan oleh Saxena, berdasarkan hasil diskusi dengan para pakar dipilih 4 elemen yang berpengaruh secara dominan, yaitu (1) sektor masyarakat yang terpengaruh, (2) tujuan dari program, (3) aktivitas yang dibutuhkan guna perencanaan tindakan dan (4) lembaga yang terlibat dalam pelaksanaan program.

ISM digunakan untuk melihat struktur hubungan antara subelemen-subelemen di dalam sistem. ISM juga menghasilkan output berupa matrix driver power-dependence, yaitu plot subelemen ke dalam empat sektor yang menggambarkan besarnya tingkat daya dorong dan ketergantungan subelemen di dalam sistem. Model kebijakan pengendalian harga bahan pokok perlu memprioritaskan pada subelemen kunci dari masing-masing elemen sistem. Subelemen kunci tersebut akan mampu menggerakkan subelemen yang lainnya untuk mendukung keberhasilan kebijakan pengendalian harga bahan pokok. Posisi antar subelemen yang berbeda dalam kuadran, menjadikan hubungan antar subelemen menjadi sangat dinamis dan saling terkait, sehingga perlu dicermati dengan seksama dalam merancangnya (Ansyar, 2018.

\section{Elemen sektor masyarakat yang terpengaruh}

Elemen sektor masyarakat yang terpengaruh dalam merancang model kebijakan pengendalian harga bahan pokok terdiri dari 4 subelemen. Disajikan dalam bentuk hirarki pada Gambar 1. Subelemen kunci dari sektor masyarakat yang terpengaruh adalah Pemerintah Daerah (A1). Hal ini berarti Pemerintah Daerah merupakan sektor masyarakat yang paling terpengaruh dan sekaligus pendorong utama yang menentukan keberhasilan kebijakan pengendalian harga bahan pokok. Pemerintah Daerah sebagai subelemen kunci akan mempengaruhi atau menggerakkan subelemen-subelemen dari elemen sektor masyarakat yang terpengaruh lainnya.

Pemerintah Daerah sebagai subelemen kunci akan menggerakkan subelemen-subelemen lain seperti Produsen (A2) agar meningkatkan produksinya, Pedagang (distributor-pengecer) (A3) agar senantiasa melakukan praktek perdagangan yang fair dan tidak melanggar peraturan perundangundangan yang berlaku, dan Konsumen akhir (A4) agar bisa mendapatkan harga yang kompetitif.

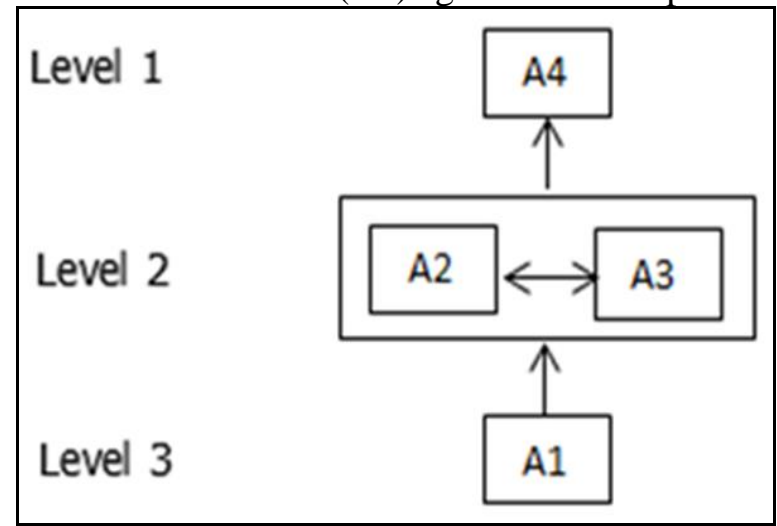

Gambar 1. Diagram model struktural dari elemen masyarakat yang terpengaruh (Sumber : data prmer diolah, 2020) 
Analisis mendalam pada matriks driver power dependence (Gambar 2.), subelemen terdistribusi dalam dtiga sektor, yaitu sektor IV, sektor III dan sektor II. Pemerintah Daerah (A1) berada di sektor IV (independent), yang berarti subelemen tersebut memiliki daya dorong atau kekuatan penggerak (driver power) yang besar, namun memiliki sedikit ketergantungan terhadap sistem. Subelemen yang berada di sektor IV (independent) memiliki daya dorong atau kekuatan penggerak (driver power) yang besar terhadap keberhasilan kebijakan pengendalian harga bahan pokok.

Produsen (A2) dan Pedagang (distributor-pengecer) (A3) berada pada sektor III (linkage), yang berarti saling berpengaruh dengan subelemen lainnya. Subelemen yang berada di sektor III merupakan subelemen yang labil. Kurangnya perhatian pada subelemen tersebut akan menjadi penghambat keberhasilan kebijakan pengendalian harga bahan pokok. Subelemen tersebut merupakan pelaku usaha yang terlibat dalam pengadaan dan distribusi bahan pokok. Subelemen tersebut juga terlibat dalam penentuan harga bahan pokok.

Konsumen akhir (A4) merupakan subelemen yang berada pada sektor II (dependent), yang berarti memiliki pengaruh yang kecil pada sistem dan paling terdampak oleh kebijakan dalam sistem. Dengan begitu subelemen tersebut tidak memiliki power dalam mempengaruhi kebijakan pengendalian harga kebutuhan bahan pokok.

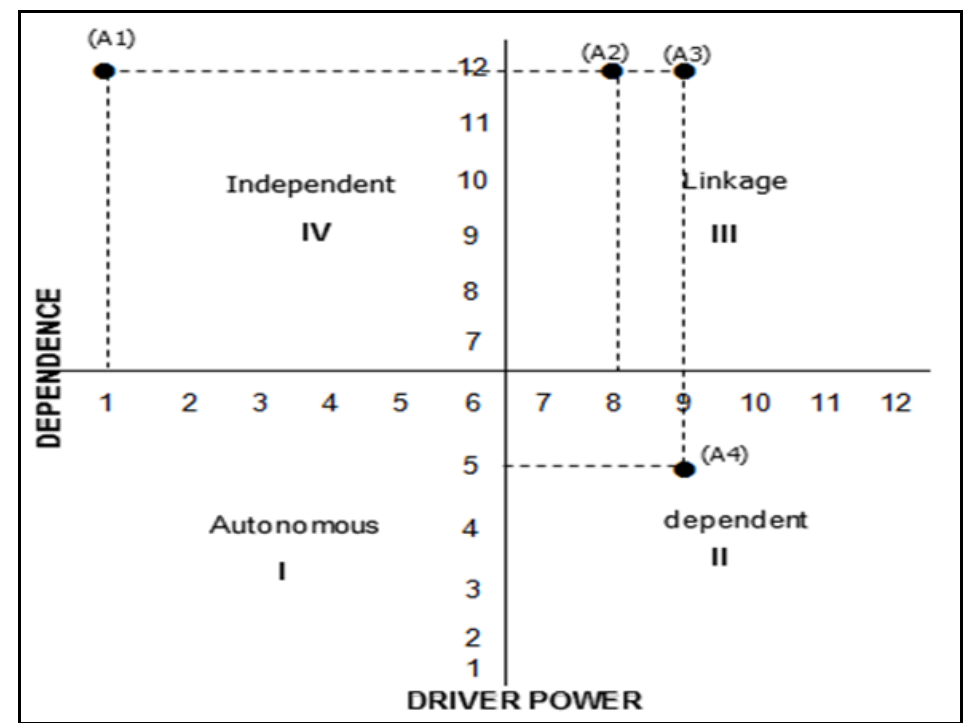

Gambar 2 Matriks driver power-dependence untuk elemen masyarakat yang terpengaruh (Sumber : data prmer diolah, 2020)

Keterangan :

A1 : Pemerintah Daerah

A2: Produsen

A3 : Pedagang (distributor-pengecer)

A4 : Konsumen akhir

\section{Elemen tujuan program}

Elemen sektor tujuan dari program pada kebijakan pengendalian harga bahan pokok terdiri dari 3 sub elemen. Disajikan dalam bentuk hirarki pada Gambar 3. mengalokasikan anggaran untuk pengendalian harga bahan pokok (A3) dan mengendalikan harga bahan pokok (A1) merupakan subelemen kunci dari elemen tujuan dari program. Subelemen kunci tersebut akan mempengaruhi atau menggerakkan subelemen pada level diatasnya yaitu mengendalikan inflasi harga bahan pokok dan penting (A2). Jika tujuan pada subelemen kunci tidak terwujud, akan sulit mewujudkan tujuantujuan pada level diatasnya. 


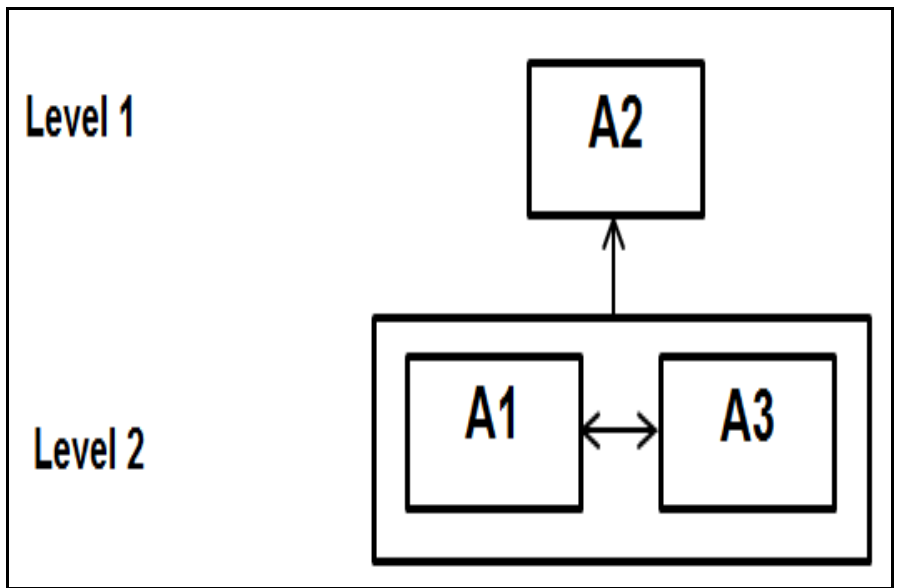

Gambar 3. Diagram model struktural dari elemen tujuan program (Sumber : data prmer diolah, 2020)

Matriks driver power dependence (Gambar 4) menunjukkan tiga subelemen menempati sektor IV (independent) yaitu mengalokasikan anggaran untuk pengendalian harga bahan pokok (A3), mengendalikan harga bahan pokok (A1) dan mengendalikan inflasi harga bahan pokok (A2), yang berarti ketiga sub elemen tersebut mempunyai daya dorong yang kuat, tetapi memiliki sedikit ketergantungan terhadap sistem. Dengan begitu agar tujuan dari program ini dapat terwujud maka ketiga subelemen tersebut harus dapat diwujudkan.

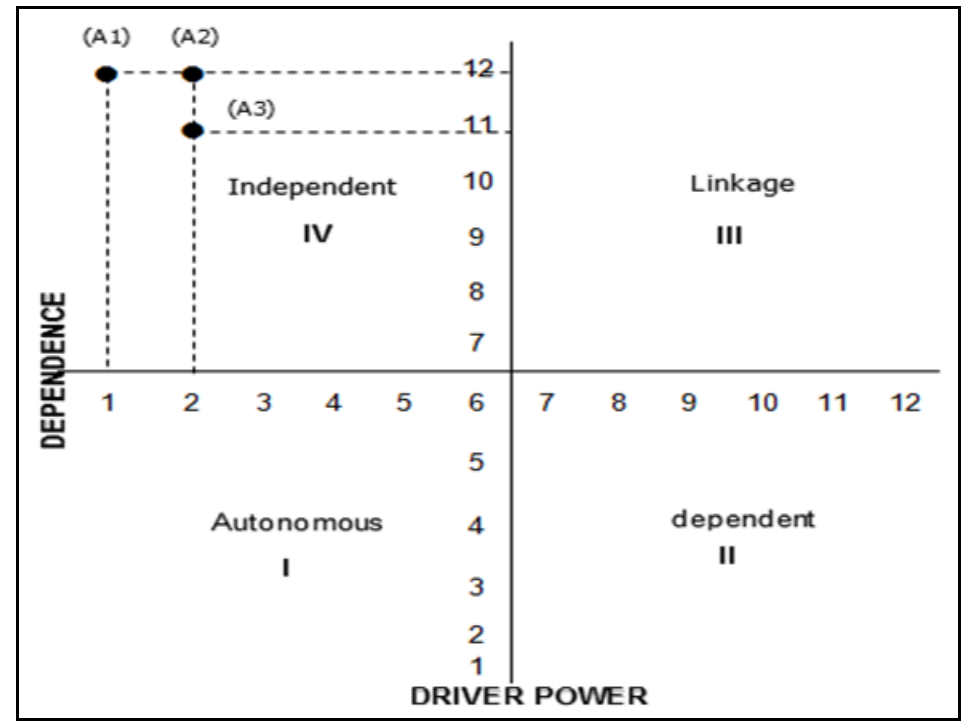

Gambar 4. Matriks driver power-dependence untuk elemen tujuan program (Sumber : data prmer diolah, 2020)

Keterangan :

Al : Mengendalikan harga bahan pokok

A2 : Mengendalikan inflasi harga bahan pokok

A3 : Mengalokasikan anggaran untuk pengendalian

harga bahan pokok

\section{Elemen aktivitas yang dibutuhkan guna perencanaan tindakan}

Elemen aktivitas yang dibutuhkan untuk kebijakan pengalokasian anggaran untuk pengendalian harga bahan pokok tersusun dari sepuluh subelemen yang terbagi dalam tujuh level (Gambar 5). Subelemen kunci dari elemen aktivitas yang akan mendorong aktivitas yang lain adalah meningkatkan kinerja Tim pengendali inflasi daerah (TPID) (A9). Aktivitas subelemen kunci tersebut harus di jalankan terlebih dahulu sebelum akivitas lainnya yang berada di level di atasnya, yaitu memantau kondisi stok, distribusi dan perkembangan harga (A2) yang juga akan 
menggerakkan level diatasnya, yaitu memberikan informasi real time terkait perkembangan harga melalui media (A4), demikian seterusnya.

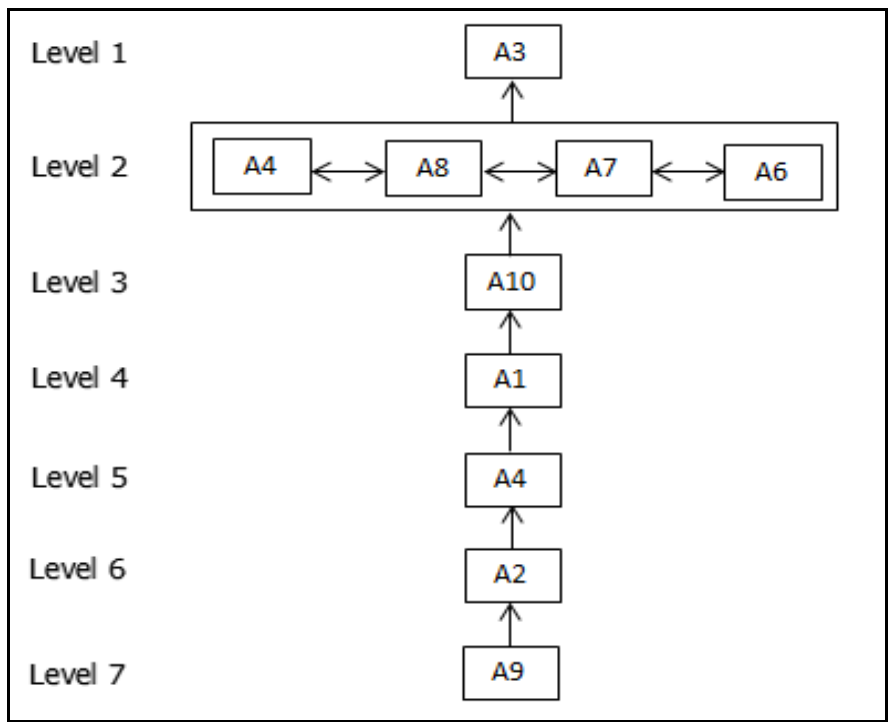

Gambar 5. Diagram model struktural dari elemen aktivitas yang dibutuhkan guna perencanaan tindakan (Sumber : data prmer diolah, 2020)

Matriks driver power dependence (Gambar 6) menunjukkan lima subelemen menempati sektor IV (independent) yaitu meningkatkan kinerja Tim pengendali inflasi daerah (TPID) (A9), memantau kondisi stok, distribusi dan perkembangan harga (A2), memberikan informasi real time terkait perkembangan harga melalui media (A4), membuat pusat krisis pengendalian harga kebutuhan pokok. (untuk memantau dan mengatasi masalah pangan dengan cepat,) (A1) dan mengadakan kerja sama perdagangan dengan daerah lain (A10), yang berarti kelima subelemen tersebut mempunyai daya dorong yang kuat, tetapi memiliki sedikit ketergantungan terhadap sistem.

Subelemen berada di sektor III (linkage) yang berarti memiliki daya dorong yang kuat dan saling terikat satu sama lain, sehingga subelemen yang berada pada sektor ini harus benar-benar diperhatikan. Subelemen yang berada pada sektor ini meliputi membuat pusat krisis pengendalian harga (A1), meningkatkan dan melindungi produksi; (A8), meningkatkan kelancaran arus distribusi; (A7), menyediakan subsidi ongkos angkut (A6) dan melakukan kegiatan operasi pasar (A3)

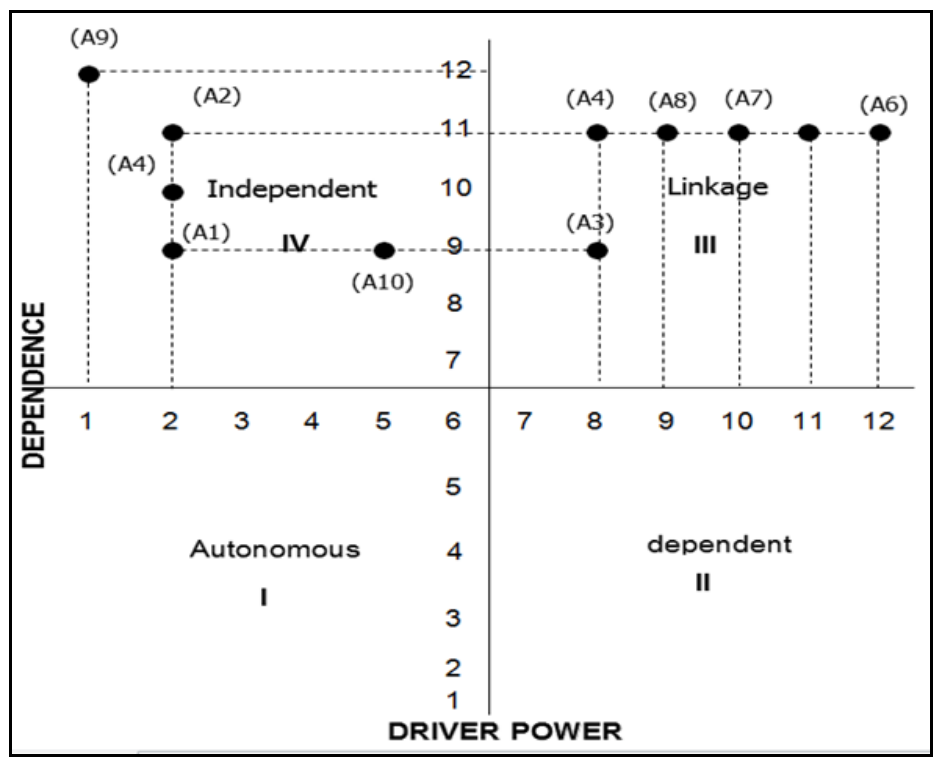

Gambar 6. Matriks driver power-dependence untuk elemen aktivitas yang dibutuhkan guna perencanaan tindakan (Sumber : data prmer diolah, 2020) 
Keterangan :

A1 : Membuat pusat krisis pengendalian harga

A2 : Memantau kondisi stok, distribusi dan perkembangan harga

A3 : Melakukan kegiatan operasi pasar

A4 : Memberikan informasi real time terkait perkembangan harga melalui media

A5 : Mengelola stok dan logistik;

A6 : Menyediakan subsidi ongkos angkut

A7 : Meningkatkan kelancaran arus distribusi;

A8 : Meningkatkan dan melindungi produksi;

A9 : Meningkatkan kinerja Tim Pengendali Inflasi Daerah (TPID)

A10 : Mengadakan kerja sama perdagangan dengan daerah lain

\section{Elemen Lembaga Yang Terlibat Dalam Pelaksanaan Program}

Elemen lembaga yang terlibat dalam kebijakan pengendalian harga bahan pokok terdiri dari tujuh subelemen yang terbagi dalam empat level (Gambar 7). Sub elemen kunci dari elemen lembaga yang terlibat dalam kebijakan pengendalian harga bahan pokok adalah internal Pemerintah Daerah (A1) dan DPRD (A2), yang berarti sub elemen kunci tersebut akan dapat menggerakkan sub elemen yang lain di level atasnya untuk keberhasilan program kebijakan pengendalian harga bahan pokok.

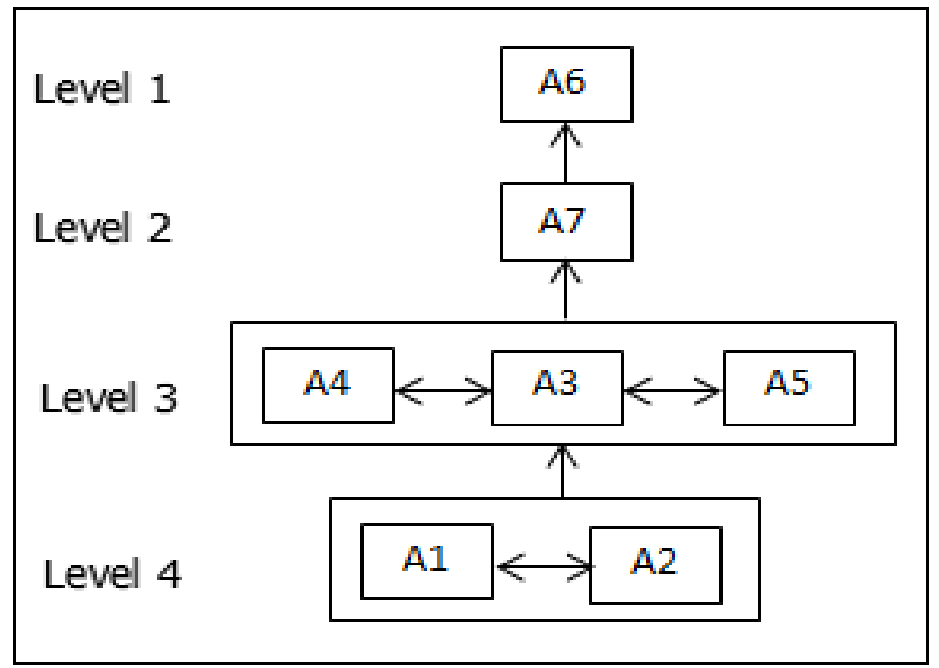

Gambar 7. Diagram model struktural dari elemen lembaga yang terlibat dalam pelaksanaan program (Sumber : data prmer diolah, 2020)

Analisis lebih lanjut pada matriks driver power-dependence, seperti yang disajikan pada Gambar 8., menunjukkan subelemen lembaga yang terlibat dalam program kebijakan pengendalian harga bahan pokok terbagi ke dalam dua sektor. Pada sektor III (linkage) terdapat lima subelemen yaitu POLRI (A4), Kejaksaan (A3), TNI (A5), Asosiasi pelaku usaha/Pedagang (A7) dan Lembaga Swadaya Masyarakat (LSM) (A6), yang berarti subelemen-subelemen tersebut memiliki daya dorong yang tinggi dan memiliki keterkaitan yang kuat dengan subelemen yang lain untuk keberhasilan sistem, sehingga diperlukan perhatian terhadap subelemen-subelemen tersebut. Subelemen-subelemen yang berada pada sektor III (linkage), selain memiliki keterkaitan antara subelemen-subelemn yang satu dengan yang lainnya, Subelemen-subelemen tersebut juga memiliki peran yang berbeda-beda.

Pada sektor VI terdapat subelemen Pemerintah Daerah (A1) dan DPRD (A2), yang berarti kedua subelemen tersebut memiliki daya dorong yang kuat untuk keberhasilan sistem, tetapi memiliki keterkaitan yang rendah dengan subelemen yang lain di dalam sistem. Oleh karena itu 
Pemerintah Daerah dan DPRD harus mampu menjadi motor penggerak dalam upaya mewujudkan keberhasilan program kebijakan pengendalian harga bahan pokok.

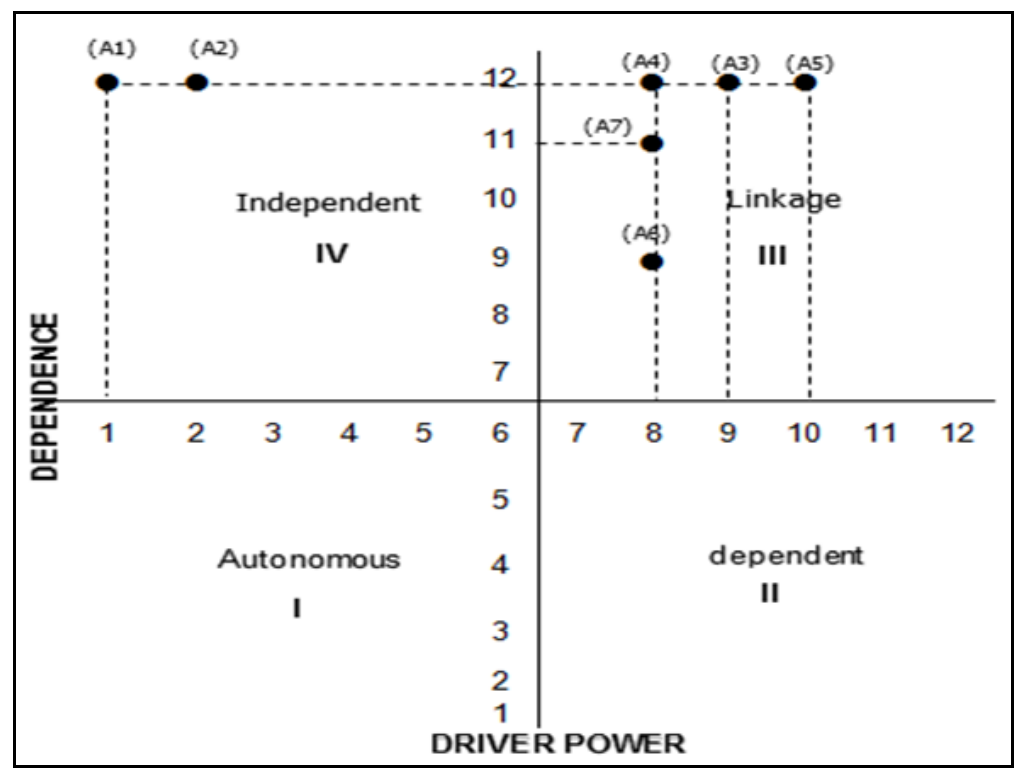

Gambar 8. Matriks driver power-dependence untuk elemen lembaga yang terlibat dalam Keterangan : pelaksanaan program (Sumber : data prmer diolah, 2020)

A1 : Pemerintah Daerah

$A 2: D P R D$

$A 3:$ Kejaksaan

A4 : POLRI

A4 : TNI

A5 : Lembaga Swadaya Masyarakat (LSM)

A6 : Asosiasi pelaku usaha/Pedagang

Hasil strukturisasi seluruh elemen pada model kebijakan pengendalian harga bahan pokok, mengasilkan subelemen kunci untuk masing-masing elemen seperti terlihat pada Gambar 9. berikut

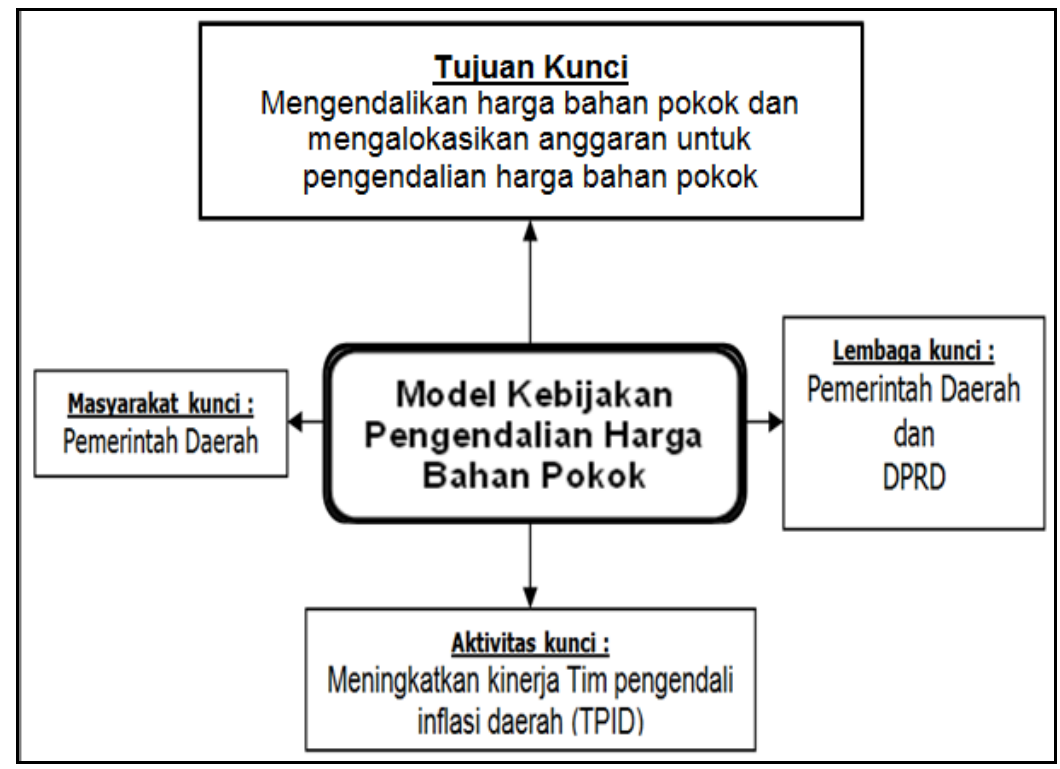

Gambar 9. Model Kebijakan Pengendalian Harga Bahan Pokok (Sumber : data prmer diolah, 2020)

Berdasarkan Gambar 9 diatas terlihat bahwa model kebijakan pengendalian harga bahan pokok pada masa pandemi covid-19 di Kabupaten Situbondo terdiri dari empat elemen kunci yang 
terdiri dari (1) tujuan kunci, yaitu mengendalikan harga bahan pokok dan mengalokasikan anggaran untuk pengendalian harga bahan pokok, dalam hal ini program harus fokus pada pengendalian harga dan alokasi anggaran untuk pengendalian harga, (2) masyarakat kunci, yaitu Pemerintah Daerah, dalam hal ini Pemerintah Daerah menjadi pendorong kunci terhadap keberhasilan pengendalian harga bahan pokok, (3) aktivitas kunci, yaitu meningkatkan kinerja Tim Pengendali Inflasi Daerah (TPID), dalam hal ini kualitas kinerja TPID akan menentukan keberhasilan program pengendalian harga bahan pokok dan (4) lembaga kunci, yaitu Pemerintah Daerah dan DPRD, hal ini diperlukan sinergitas yang kuat antara pemerintah Daerah (eksekutif) dengan DPRD (legislatif) dalam melahirkan kebijakan berupa Peraturan Daerah tentang pengendalian harga bahan pokok. Keempat elemen kunci tersebut akan menjadi motor terwujudnya stabilitas harga bahan pokok pada masa pandemi covid-19 di Kabupaten Situbondo.

\section{KESIMPULAN}

Model kebijakan pengendalian harga bahan pokok pada masa pandemi covid-19 di Kabupaten Situbondo terdiri dari empat elemen kunci yang terdiri dari (1) tujuan kunci, yaitu mengendalikan harga bahan pokok dan mengalokasikan anggaran untuk pengendalian harga bahan pokok, dalam hal ini program harus fokus pada pengendalian harga dan alokasi anggaran untuk pengendalian harga, (2) masyarakat kunci, yaitu Pemerintah Daerah, dalam hal ini Pemerintah Daerah menjadi pendorong kunci terhadap keberhasilan pengendalian harga bahan pokok, (3) aktivitas kunci, yaitu meningkatkan kinerja Tim Pengendali Inflasi Daerah (TPID), dalam hal ini kualitas kinerja TPID akan menentukan keberhasilan program pengendalian harga bahan pokok dan (4) lembaga kunci, yaitu Pemerintah Daerah dan DPRD, hal ini diperlukan sinergitas yang kuat antara pemerintah Daerah (eksekutif) dengan DPRD (legislatif) dalam melahirkan kebijakan berupa Peraturan Daerah tentang pengendalian harga bahan pokok. Keempat elemen kunci tersebut akan menjadi motor terwujudnya stabilitas harga bahan pokok pada masa pandemi covid-19 di Kabupaten Situbondo

\section{DAFTAR PUSTAKA}

Anonimous. 2020. Krisis ekonomi akibat Covid-19: IMF perkirakan 'luka ekonomi' karena krisis global akibat pandemi virus corona lebih buruk dari perkiraan. BBC News. https://www.bbc.com/indonesia/dunia-53168814

Ansyar. 2018. Determinan Dan Penentuan Lembaga Pelaku Pengembangan Usahatani Organik Dan Non-Organik Di Kabupaten Enrekang. Tesis. Program Pascasarjana Universitas Hasanuddin Makassar

Disperindag, 2020. Monitoring Harga Bahan Pokok dan Bahan Penting di Tingkat Pengecer Kabupaten Situbondo Tahun 2020. Laporan Akhir. Dinas Perdagangan dan Perindustrian Kabupaten Situbondo

Fadhil. R, M. S. Maarif, T. Bantacut dan A. Hermawan. 2018. Formulation For Development Strategy Of Gayo Coffee Agroindustry Institution Using Interpretive Structural Modeling (ISM). Acta Universitatis Agriculturae Et Silviculturae Mendelianae Brunensis. V. 66 N0. 2. P. 487-495. https://ideas.repec.org/a/mup/actaun/actaun_2018066020487.html

Manzilati, A. 2017. Metodologi Penelitian Kualitatif Paradigma, Metode, dan Aplikasi. Malang: UB Press.

Hasan, S. 2016. Peran Pemerintah Dalam Perlindungan Dan Pemberdayaan Pasar Tradisional Di Kota Makassar. Skripsi. Program Studi Ilmu Pemerintahan, Fakultas Ilmu Sosial dan Ilmu Politik, Universitas Hasanuddin.http://repository.unhas.ac.id/bitstream/handle/123456789/19124/Skripsi\%20Saifu $\underline{\text { llah\%20Hasan\%20E12112013.pdf?sequence }=1}$ 
Rahmi, A. 2013. Mekanisme Pasar dalam Islam. Jurnal Ekonomi Bisnis dan Kewirausahaan, Vol. 4, No. 2, 177-192. https://jurnal.untan.ac.id/index.php/JJ/article/view/12481

Sianipar, M. 2012. Penerapan interpretative structural modeling (ISM) dalam penentuan elemen pelaku dalam pengembangan kelembagaan sistem bagi hasil petani kopi dan agroindustri kopi. $\begin{array}{llllllll}\text { AGROINTEK. } & \text { volume } & 6 & \text { No. } & 1 & \mathrm{P} & : & 8-15 .\end{array}$ https://journal.trunojoyo.ac.id/agrointek/article/view/1948

Sumarni. 2013. Intervensipemerintah Antara Kebutuhandan Penolakan Dibidang Ekonomi. Jurnal Program Studi Pendidikan Ekonomi STKIP PGRI Sumatera Barat Vol. 1 No.2. http://ejournal.stkip-pgri-sumbar.ac.id/index.php/economica/article/view/118 